\title{
The Model of Decision Making for The Formulation of Integrative Islamic Boarding School Curriculum (Study of Response to KMA 183 and KMA 184 2019)
}

Marjuni*

Islamic Religious Education Study Program, Institut Agama Islam Riyadlotul Mujahidin (IAIRM Ngabar), Ponorogo, Indonesia

${ }^{*}$ Corresponding author:

E-mail:

marjuniwsngabar@gmail.com

\begin{abstract}
The purpose of this research is to explain that the support system makes decisions prepared by the principle of madrasas and the implementation of integrative curriculum development, how the integrative curriculum is created using a particular model, and the model of curriculum outcomes such as those prepared by the principle. The background of this study resulted in the phenomenon of the difficulty of madrasas principle in the boarding school environment to compile an integrated curriculum structure based on KMA 183 and KMA 184. This study used a qualitative method using phenomenology, data obtained by interviews in, studios, and direct observation. This study found (1) Decision Support System Concepts based on the principle of Madrasa Aliyah Wali Songo Dormitory Sons and Madrasa Aliyah Wali Songo Dormitory Girls are separate instruments made by humans assisted by systems made by computers that function as miners, processors, responders, and decision-makers based on needs and goals. (2) Preparation of an integrative curriculum is carried out with a dynamic and statistical model at the same time because the issue of expenditure will not be handled properly only on the statistical model. The integrated curriculum model according to Robert D. Speech was taken to solve complicated problems that occurred and ended with the formalization of decisions to ensure the validity of curriculum constructs and the legitimacy of decisions. (3) Integrated madrasa curriculum formulated by the Madrasa Aliyah Wali Songo Dormitory Sons and the Madrasa Aliyah Wali Songo Dormitory Girls is the Independent Curriculum Transdisciplinary (ICT).
\end{abstract}

Keywords: Decision-making model, integrative curriculum, Islamic Boarding School Madrasa, KMA 183/2019, KMA 184/2019

\section{Introduction}

Human thought is limited by knowledge, experience, habits, values, environment, and so forth. Science can never answer all the questions in this world and will only be able to "satisfy" human curiosity limited in its scope. By being aware of the limitations of rationality, humans can think more rationally to face daily problems (Sumarsono, 2013). The complexity of the problem requires humans to make the most rational step in decision making. A Decision Support System (DSS) is an information system that is expected to help management in the decision-making process. The decision support system is an approach to support decision-making. Decision support systems use collected data, provide an easy user interface, and can incorporate the thinking of decision-makers (Turban, 2005). While the information system is a system that provides information for management in making decisions and also to run company operations, where the system is a combination of people, information technology, and procedures that are organized (Binus University, 2016). According to Eniyati (2011) states that a decision support system is a system 
of producing information aimed at a particular problem that must be solved by the manager and can help managers in making decisions. Decision support systems are an inseparable part of the totality of the overall organizational system. An organizational system includes physical systems, decision systems, and information systems (Suryadi, 2011).

The concept of a Decision Support System was first stated by Michael S. Scott Morton in 1970 with the term "Management Decision System". After the statement, several companies and universities conducted research and developed the concept of Decision Support Systems. DSS is designed to support all stages of decision making ranging from identifying problems, selecting relevant data, determining the approach used in the decision-making process, to evaluating choices (Setiyaningsih, 2015).

Decision Support System combines an individual's intellectual resources with computer capabilities to improve the quality of decision making (Saliman, 2015). A Decision Support System is defined as an addition to decision-makers, to expand capabilities, but not to replace management considerations in decision making (Whetyningtyas, 2011). In one study Steven S. Alter developed a taxonomy of six types of Decision Support Systems based on the level of problem-solving support. The Decision Support System also allows managers to see the impacts that may arise from various decisions taken called a model that can estimate the impact of a decision (Putranto, 2016). Decision Support System is intended to complement the management information system in improving decision making. Management information systems primarily present information about the performance of activities to help management monitor and control activities (Anwar, 2014).

The hierarchy of decision-making by policymakers means forming the program to be achieved, and also its implementation strategy and problem-solving strategy. The formulation is through a decision based on the results of the selection of several alternative problems that have been determined to achieve the objectives of the madrasa. The decision-making includes problem identification activities, problem formulation, and the selection of alternative decisions based on calculations and various impacts that may arise. In the implementation or operational stage, decisionmakers as leaders must make many routine decisions to control activities according to plans. The supervision stage which includes monitoring, examination and evaluation of the results of the implementation is needed to be carried out to evaluate the implementation of the decision-making that has been done (Anwar, 2014). The demand for creative thinking in decision-making is a necessity. Because in essence everyone is always faced with the choice to make decisions. To be able to make the right decision, everyone must know the steps. Creative thinking will help decisionmakers to improve the quality and effectiveness of problem-solving and the results of decisionmaking made. Regarding the decision-making process, creative thinking is needed, especially in identifying problems and developing alternative solutions (Malihah et al., 2013).

Decision support systems in the field of education have been widely applied in education as practiced by (Eriskawati et al., 2006) have developed a SAW-based decision support system with a variant of weighting values in employee recruitment. The decision support system by (Eniyati, 2011 ) is used to determine the decision of admission of new students by the SAW (Simple Additive Weighting) method. Decision-making on scholarship acceptance in an educational institution has also implemented DSS as conducted by (Setyawan, 2015) who has developed technical applications based on the integration of SAW and Java.

The problem in formulating a relatively complex madrasa curriculum requires the competency of the madrasa headmaster in elaborating all the resources (Ansani \& Baking, 2019). The Government of Indonesia through the Ministry of Religion formulated a praxis policy on madrasa curriculum as stipulated in KMA 183/2019 on Islamic Education Curriculum (PAI) and Arabic Language on Madrasas (KSKK et al., 2019a) and KMA 184/2019 on Guidelines Implementation of Curriculum in Madrasas (KSKK et al., 2019b).

Nevertheless, the implementation of the Decree of the Minister of Religion still faces problems in the practical field. One of them is the issue of Aliyah madrasa curriculum structure in Islamic boarding schools which applies an integrative curriculum between the Islamic boarding school 
curriculum and the curriculum of the Ministry of Religion. The problem faced by the madrasa is about the islamic boarding school curriculum "body" which is relatively over-arranged of implementing a relatively dense state curriculum. The problem arises because the allocation of learning hours each week in Islamic boarding schools is relatively longer and dense than in regular schools. There is almost no free space in the allocation of class hours each week. This condition forces the madrasa headmaster to take creative, real, and effective steps to design a curriculum structure that would allow integration of the implementation of the Islamic boarding school curriculum with the Ministry of Religion curriculum.

This study aims to address several issues regarding the basic concept of decision support systems by the headmaster of the Madrasa Aliyah Wali Songo Girls dorm and Madrasa Aliyah Wali Songo Girls dorm in designing an integrative curriculum, the urgency and benefits of a decision support system in designing an integrative curriculum in Madrasa Aliyah Wali Songo Girls dorm and Madrasa Aliyah Wali Songo Girls dorm, Decision Support System models used by the headmaster of Madrasa Aliyah Wali Songo Girls dorm and Madrasa Aliyah Wali Songo Girls dorm in integrative curriculum design, and the implications of the use of Decision Support Systems in the design of integrative curriculum in Madrasa Aliyah Wali Songo Girls dorm and Madrasa Aliyah Wali Songo Sons dorm. The final results of this study are expected to be able to describe the model of decision support systems that can be applied to Islamic boarding school-based madrassas, and it is hoped that an integrated madrasa curriculum model will be found in Islamic boarding schools.

\section{Material and Methods}

This research was conducted at Madrasa Aliyah Wali Songo Girls dorm and Madrasa Aliyah Wali Songo Girls dorm Wali Songo Islamic Boarding School Ngabar Ponorogo. The qualitative method was applied because the problem to be studied was natural-material scattered in the study site.

The phenomenological approach is used to find certain values that are contained in the research setting. Data were collected by in-depth interviews, documentation studies, and direct observations on the natural setting of Islamic boarding schools.

The researcher as a key instrument tries to explore the context of the issues by working with Madrasa headmaster Aliyah Wali Songo Girls dorm and headmaster of Madrasa Aliyah Wali Songo Girls dorm as key informants. The research also made several other important informants such as the Chairperson of the Santri Wali Songo Organization.

\section{Results and Discussion}

Wali Songo Ngabar Ponorogo Islamic Boarding School manages 4 (four) levels of education from Kindergarten to Higher Education. Tarbiyatul Athfal Al-Manar Al-Islamiyah as a pre-school level education unit, Madrasa Ibtidaiyah (MI) Mamba'ul Huda Al-Islamiyah as an Elementary education unit. Madrasa Tsanawiyah (MTs) Wali Songo Girls dorm, MTs Wali Songo Girls dorm, Madrasa Aliyah (MA) Wali Songo Girls dorm, and MA Wali Songo Girls dorm, each of which operated separately and is headed by a madrasa headmaster who is directly responsible to the Chair of the Islamic Boarding School. The Islamic-based higher education is the highest unit owned by Wali Songo Ngabar Islamic Boarding School, Riyadlotul Mujahidin Islamic Institute.

Headmaster of MA Wali Songo Sons dorm and headmaster of MA Wali Songo Girls dorm hold a work meeting at the beginning of the school year. The work meeting between MA Wali Songo Sons and Girls dorm was held in a special forum. This was done because the MA Wali Songo Sons dorm and Girls were managed by the Wali Songo Boarding School Ngabar Ponorogo (Pondok Ngabar) with a one-roof model.

The intended work meeting aims to formulate a strategic plan that will be implemented in the next school year. 
Tabel 1. The stakeholder meeting of the madrasa

\begin{tabular}{|c|c|c|c|}
\hline No. & Occupation & Person & Responsibility \\
\hline 1. & HeadmasterMadrasa & 2 persons & In charge of Madrasa \\
\hline 2. & Vice headmaster curriculum & 2 persons & Persons in charge of curriculum \\
\hline 3. & $\begin{array}{l}\text { Vice headmaster student } \\
\text { affairs }\end{array}$ & 2 persons & $\begin{array}{l}\text { Persons in charge of the student } \\
\text { committee }\end{array}$ \\
\hline 4. & $\begin{array}{l}\text { Vice headmaster public } \\
\text { relations }\end{array}$ & 2 persons & Persons in charge of public relations \\
\hline 5. & $\begin{array}{l}\text { Vice headmaster facilities and } \\
\text { infrastructures }\end{array}$ & 2 persons & $\begin{array}{l}\text { Persons in charge of facilities and } \\
\text { infrastructures }\end{array}$ \\
\hline 6. & Teacher & 10 persons & $\begin{array}{l}\text { Contributor of content, system } \\
\text { structures, and curriculum evaluation. }\end{array}$ \\
\hline 7. & Student advisory assembly & 6 persons & $\begin{array}{l}\text { Persons in charge of student adviser } \\
\text { and dormitories }\end{array}$ \\
\hline 8. & Madrasa Committee & 10 persons & $\begin{array}{l}\text { The party that cooperatively working } \\
\text { with Madrasa }\end{array}$ \\
\hline 9. & Foundation exchequer & 5 persons & $\begin{array}{l}\text { The manager of finance of the boarding } \\
\text { school }\end{array}$ \\
\hline 10. & $\begin{array}{l}\text { The staff of the boarding } \\
\text { school's Leader secretariat }\end{array}$ & 2 persons & $\begin{array}{l}\text { Documented and recorded the meeting } \\
\text { progress to the boarding school's } \\
\text { leader }\end{array}$ \\
\hline 11. & $\begin{array}{l}\text { The secretary staff of } \\
\text { Tarbiyatul Mu'alllimin Al- } \\
\text { Islamiyah }\end{array}$ & 2 persons & $\begin{array}{l}\text { Documented and recorded the meeting } \\
\text { progress to the Tarbiyatul Muallimin } \\
\text { Al-Islamiyah's Director }\end{array}$ \\
\hline 12. & $\begin{array}{l}\text { Wali Songo Islamic Boarding } \\
\text { School Alumni Family }\end{array}$ & 2 persons & $\begin{array}{l}\text { Ideas contributor and data alumni data } \\
\text { provider. }\end{array}$ \\
\hline 13. & $\begin{array}{l}\text { Organizers of the Santri Wali } \\
\text { Songo Organization }\end{array}$ & 2 persons & $\begin{array}{l}\text { Controller student advisor affairs and } \\
\text { directly responsible to the student's } \\
\text { supervisory assembly. }\end{array}$ \\
\hline
\end{tabular}

Decision-making is carried out in MA Wali Songo Sons and Girls dorm in terms of aspects of decision-making goals included in the category of "research models" not "training models". This is showed by the real efforts of madrasa stakeholders in making important madrasa decisions through the annual madrasa work meeting.

Meanwhile, because decision-making does not only depends on the results of annual work meetings, it can be categorized as dynamic -from them an aspect of decision-making time. The annual work meeting is a form of static decision-making model. MA Wali Songo Sons dorm and MA Wali Songo Girls dorm applied two kinds of models, namely static and dynamic.

The form of decision-making is done multidimensionally. Judged from the composition of participants who contribute to decision making. Multidimensionalization of the perspectives of decision-makers encouraged MA Wali Songo Sons dorm and MA Wali Songo Girls dorm to implement analytic decision-making forms. Analysis of the problems faced by madrassas from various perspectives and heterogeneity of policymakers to apply the holistic model in terms of the complexity of the problems being solved.

Decisions made through annual work meetings are carried out jointly and monitored together, then evaluated together at the next annual work meeting. The formalization of decisionmaking is carried out with two objectives, namely, firstly, creating a climate of shared responsibility for madrassas, and, secondly, demanding the implementation of all work programs that have been decided to achieve certain specified quality standards. 
The madrasa strategic plan can be formulated through this annual work meeting. so that several important decisions such as Madrasa Self Evaluation (MSE), Madrasa Work Plan (MWP), Madrasa Financial and Budget Plan (MFBP), Madrasa Annual Work Plan (MAWP), and even Madrasa Development Plan (MDP) can be established.

The leadership of Wali Songo Islamic Boarding School uses collegial collective leadership consisting of three boarding leaders. Each of the three boarding house leaders has the same authority, although they have various main duties and functions. The same authority of each headmaster of the boarding school has the right to take the policy, but it is limited by Majlisu Riyasatil Ma'had.

Majlisu Riyasatil Ma'had has the right to elect and dismiss the leadership of the boarding school. Majlisu Riyasati al-Ma'had is the highest institution in the Wali Songo Ngabar Boarding School which has the authority to elect the leader of the boarding school and the right to be elected as the leader of the Wali Songo boarding school, and also has the authority to determine the direction of the Wali Songo Ngabar boarding school.

Therefore, it can be referred to as the People's Consultative Assembly in the governance of Indonesia. This is only as an analogy to facilitate understanding of the description of the main tasks, functions, and authority of the institution within the Wali Songo Ngabar Ponorogo. The boarding school does not intend to equate the degree of this institution with the government institution in Indonesia which is commonly called the People's Consultative Assembly.

The headmaster of the Madrasa in the Wali Songo Ngabar Ponorogo Boarding School is elected by the Boarding School Leaders, not by the Foundation. The madrasa headmaster is responsible to the headmaster of the boarding school. While the leader of the boarding house is responsible for Majlisu Riyasatil Ma'had

Majlisu Riyasatil Ma'had is responsible for carrying out the $w^{\prime} a f^{1}$ mandate. The Majlis consists of 15 (fifteen) people who are appointed and suitable in the Majlis Statutes and By-Laws. Majlis membership lasts a lifetime unless the member resigned or passed away. Majlis conducts meetings at least once a year to listen and listen to reports on the performance of the leaders of the boarding school. Majlis holds a session every five years to elect and decide the leadership of the boarding school.

The elected board chair carries out the mandate for 5 years in 1 period and can be re-elected in the next period in an assembly session. The Boarding School Leaders appoint the leaders of the institutions to carry out the task of managing education.

In addition to the institution that manages formal education, Islamic Boarding School Wali Songo Ngabar, both dorms, has another institution that is responsible to maintain and improve the study and students' performance. That fellow institution is named Majlis of Students Mentor for Sons and Girls, both institutions functioned as student care and center, then hand the report to the boarding school leader.

The management of formal education by the Wali Songo Ngabar Islamic Boarding School, which at its praxis level is managed by Tarbiyatul Mu'allimin and Tarbiyatul Muallimat AlIslamiyah, has delegated the authority of making educational curriculum policies to each designated madrasa head. Nevertheless, the Director of Tarbiyatul Muallimin Al-Islamiyah (TMI) and the Director of Tarbiyatul Muallimat Al-Islamiyah (TMt-I) consisting of each of the 3 (three) people included as chief madrasa officials. This structure facilitates TMI and TMt-I in managing education management.

\footnotetext{
${ }^{1}$ Waqf is a legal act of endowment to separate and / or surrender a part of his property to be used forever or for a certain period in accordance with his interests for the purposes of worship and/or public welfare in accordance with sharia
} 
Madrasa Aliyah Wali Songo Sons dorm and Madrasa Aliyah Wali Songo Girls dorm which is part of the TMI and TMt-I Tarbiyatul Muallimin (TMI) and Tarbiyatul Muallimat Al-Islamiyah (TMT-I) decisions.

The TMI and TMt-I profiles can be described as follows.

A. Vision

Graduating the student with good Islamic characteristics, excellent achievement, and competitive theoretical and practical knowledge in the fields of Dirosiyah Islamic, Arabic, English, and Science in the Global Era.

B. Mission

1. Organizing education and teaching in the fields of Dirosah Islamiyah, Arabic, English, and Science that are characterized by an Islamic boarding school, superior and competitive.

2. Develop theoretical and practical skills in the fields of Dirosah Islamiyah, Arabic, English, and Science.

3. Increasing the quality of sustainable management of Tarbiyatul Mu'allimin Al-Islamiyah effectively and efficiently.

4. Develop adequate educational and teaching support facilities.

5. Developing cooperation with various parties, both domestic and foreign, to increase and develop capabilities in the fields of Dirosah Islamiyah, Arabic/English, and Science.

C. Purpose

1. The implementation of education and teaching in the fields of Dirosah Islamiyah, Arabic, English, and Science that are characterized by an Islamic boarding school, superior and competitive.

2. The realization of improving the quality of religious teachers and students theoretically and practically in the fields of Dirosah Islamiyah, Arabic, English, and Science.

3. The realization of sustainable quality in the management of Tarbiyatul Mu'allimin $\mathrm{Al}$ Islamiyah effectively and efficiently.

4. The realization of adequate educational and teaching support facilities.

5. The realization of cooperation with various parties, both at home and abroad, to increase and development in the fields of Dirosah Islamiyah, Arabic, English, and Science

D. TMI/TMt-I ISSUES Currently

1. External Issues

a. The increment of competitive and quality Islamic Education Institutions.

b. Global challenges are increasingly uncertain/completely uncertain

c. Moral distortion in the Global era.

d. The requirement for an action to realize an Educational Institution capable of producing morally competent people who practically understand Islam, science, and skills in the future.

2. Internal Issues

a. Management stagnation (Grand Design), strategy (How to realize Vision), and model (Institutional Idealism/value) of education at TMI.

b. Teachers who have not yet met Academic, Professional, Pedagogic, and Social qualifications.

c. The low percentage of competitiveness of TMI graduates to enter domestic and foreign universities.

d. TMI infrastructure is inadequate.

e. The curriculum has not been arranged following the Vision of Wali Songo Islamic Boarding School Ngabar Ponorogo as set out in the Direction and Objectives of Education in Wali Songo Islamic Boarding School Ngabar Ponorogo.

E. TMI/TMt-I Objective Conditions

1. On External Issues 
a. TMI is not ready to compete with competitive and quality Islamic Education Institutions

b. TMI has not formulated a clear and accurate foothold in creating alumni who are ready to respond to global challenges.

c. TMI requires preparing alumni who can withstand moral decadence.

d. TMI aspires to be an Islamic Education Institution capable of producing morally competent, scientifically and skillfully cadres of Islamic cadres.

2. Against Internal Issues

a. Required to develop a Grand Design Management, Quality Achievement Strategy and Model (value) excellence TMI.

b. Required to Improve the Quality of Human Resources (Teacher)

c. Required to improve the quality of Santri Academic

d. Required to increase the adequacy of Facilities and Infrastructure supporting the Education process at TMI

e. TMI curriculum needs to be developed following the direction and objectives of Education in PPWS.

E. TMI/TMt-I Driven \& Obstacles

1. Elements of Push/Opportunity and Strength

a. Islamic boarding school System.

b. Full support of the Decision Maker (Boarding School and Foundation Chairmen).

c. Stakeholder TMI and TMt-I commitment to advance the Institute.

d. The high sense of belonging of the TMI and TMt-I teacher (Ruh Al-Jihad).

e. The level of public trust in PPWS began to improve.

2. Obstacles/Challenges and Weaknesses

a. An organizational system that has not been running well.

b. Low ability/competence of TMI and TMt-I organizational actors.

c. The low motivation and work ethic of education practitioners in TMI and TMtI.

d. Weak quality of HR for Educational Performers at TMI and TMt-I.

e. Inadequate facilities and infrastructure.

F. Limitations (Working Context) TMI/TMt-I

1. Improving the quality of teachers and students in the mastery of Dirosah Islamiyah

2. Improving the quality of teachers and students in mastering Arabic and English

3. Improving the Quality of Teachers and Students in the mastering of Science (Science and Technology).

Crucial issues in the MA Wali Songo both dormitories are the limited number of classrooms, lack of teachers, and the need-improve quality of teachers, including the integrity and performance, and book availability.

Because the curriculum in pesantren so far has different characteristics, for that curriculum at Wali Songo Ngabar, Islamic Boarding School also has its characteristics. These characteristics refer to the cultural, philosophical background and goals set by the founders. Educational background, social culture among the founders, and their ideas and vision, the clerics' mission determine this characteristic difference.

Madrasa curriculum management in Islamic boarding schools such as in MA Wali Songo for Sons and Girls, Ngabar Dormitory is unique. Its uniqueness is shown in the following table. 
Tabel 2. Curriculum structure of MA Wali Songo Sons dorm dan MA Wali Songo Girls dorm

$$
\text { Grade }
$$

School subject

XII XI X

N S

Natural Social Natural Social Natural Social

Science Science Science Science Science Science

\begin{tabular}{|c|c|c|c|c|c|c|c|}
\hline 1 & 2 & 3 & 4 & 5 & 6 & 7 & 8 \\
\hline Insya' & 2 & 2 & 2 & 2 & 2 & 2 & 5 \\
\hline Muthola'ah & 2 & 2 & 2 & 2 & 2 & 2 & 5 \\
\hline Mahfudzot & 1 & 1 & 2 & 2 & 2 & 2 & 5 \\
\hline Nahwu & 3 & 3 & 3 & 3 & 3 & 3 & 4 \\
\hline Arabic & 1 & 1 & 1 & 1 & 2 & 2 & 5 \\
\hline Hadits Bil Kitab & 1 & 1 & 1 & 1 & 1 & 1 & 5 \\
\hline Tafsir & 2 & 2 & 2 & 2 & 2 & 2 & 5 \\
\hline Mustholah Hadits & 1 & 1 & 1 & 1 & 1 & 1 & 4 \\
\hline Tauhid & 1 & 1 & 1 & 1 & 2 & 2 & 5 \\
\hline Fiqih & 2 & 2 & 2 & 2 & 2 & 2 & 5 \\
\hline Ushul Fiqh & 2 & 2 & 2 & 2 & 2 & 2 & 4 \\
\hline Tarikh Islam/SKI & 1 & 1 & 1 & 1 & 1 & 1 & 5 \\
\hline Geography & & 2 & & 2 & & 2 & 6 \\
\hline History & 1 & 1 & 1 & 1 & 1 & 1 & 6 \\
\hline Mathemathics & 3 & 3 & 3 & 3 & 3 & 3 & 6 \\
\hline Physics & 2 & & 2 & & 2 & & 6 \\
\hline Biology & 2 & & 2 & & 2 & & 6 \\
\hline Chemistry & 2 & & 2 & & 2 & & 6 \\
\hline Tarbiyah & 3 & 3 & 3 & 3 & 2 & 2 & 5 \\
\hline Civic education & 1 & 1 & 1 & 1 & 1 & 1 & 6 \\
\hline Sosiology & & 2 & & 2 & & 2 & 6 \\
\hline To be continued & & & & & & & \\
\hline
\end{tabular}




\begin{tabular}{|c|c|c|c|c|c|c|c|}
\hline $\begin{array}{l}\text { Indonesian Lan- } \\
\text { guage }\end{array}$ & 2 & 2 & 2 & 2 & 2 & 2 & 6 \\
\hline English & 3 & 3 & 2 & 2 & 2 & 2 & 6 \\
\hline Grammar & 2 & 2 & 2 & 2 & 1 & 1 & 5 \\
\hline Economy & & 2 & & 2 & & 2 & 6 \\
\hline $\begin{array}{l}\text { Learning hours } \\
\text { per week }\end{array}$ & 40 & 40 & 40 & 40 & 40 & 40 & \\
\hline
\end{tabular}

The curriculum structure formulated by the headmaster of Madrasa Aliyah (MA) Wali Songo Sons dorm and Madrasa Aliyah Wali Songo Girls dorm as listed above are carried out through the Complete Annual Work Meeting (CAWM). The work meeting referred to is complete because it involves all elements of the organization responsible for the Wali Songo Boarding School Ngabar Ponorogo. The decision-making model carried out as above aims to ensure that decisions made through consensus are many parties within the framework of guaranteeing the validity of the curriculum construct.

Historically only emerged in the mid-1960s as a prominent discipline within the scope of public administration and political science. Problem the most important thing that is in the spotlight is education policy is a part of public policy. Decision-making in education as part of public policy requires relatively high accountability. The policies that govern education are already very numerous, to facilitate and provide space for Indonesian education personnel to continue to innovate and build character education in line with educational expectations national. Many factors also play a role in improving the quality of education in general, some of these factors are factors of educational goals, educators, students, educational and environmental tools. So, education is a system that cannot be run right if one of the sub-systems has a problem and the result is not the optimal role of each sub-system to achieve the stated goals. Madrasa is a producer of educational services that is responsible for producing human resources of students following national education goals. Even though the education policy taken by the madrasa headmaster is local in the internal context of the madrasa, the policy implications can significantly influence the quality of the educational products it produces.

Deliberation of consensus through curriculum annual meetings shows the occurrence of nonconflict policy formulation. The complexity of the problems that often happen in Islamic boarding school-based madrassas can at least be immediately resolved when all policies consider many aspects of various interested parties.

Analytic development in curriculum development in Madrasa Aliyah Wali Songo Sons dorm and Madrasa Aliyah Wali Songo Girls dorm, at least can be seen from the theory of Robert D. Speech (Hapsari, 2005) offers many models that enable an organization to carry out its actions, among others, Combination of verbal, mathematical, computer simulation, Physical, game operational. Policy analysis in decision making is included in the category of Computer Simulation Analytics (CSA).

In the annual curriculum meeting, the headmaster of madrasa involves all parties in the Islamic boarding school environment to contribute to the formulation of the curriculum. The underlying reason is because of the complexity of the problems that exist in Islamic boarding schools. While curriculum development is carried out formally and the results are outlined in an official decision, then disseminated to all stakeholders, indicating the formalization of policies.

Research conducted by Thora proves that the decision support system with the Fuzzy method can help and facilitate the school in the process of maximum identification related to the level of 
damage to school buildings (Thora, 2015). Sumiati and Nuryadin (2013) reported that decision support systems have contributed to the emergence of alternative lecturer assessment systems, the development of performance criteria, to provide reward and or punishment. Evy (2015) also reports that APOS Theory can be applied to identify student learning styles, which in turn encourages schools to develop educational programs, encourages teachers to ensure their learning activities are following student needs, encouraging students to improve their learning achievement. Students are free to choose learning styles according to their needs.

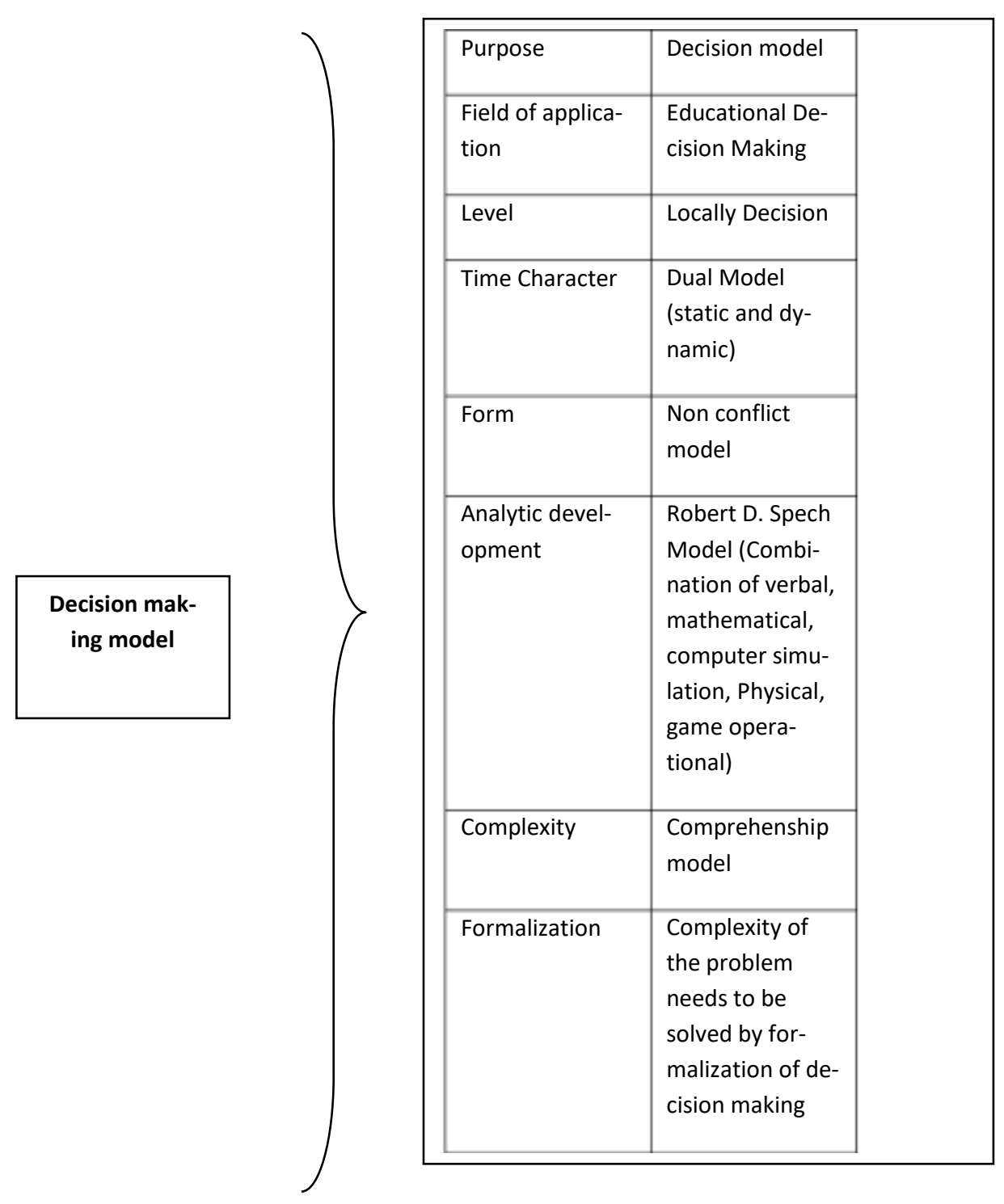

Figure 1. Decision-making model (Hapsari, 2005)

Lately, many universities have taken strategic steps to deal with the Industrial era's phenomenon. Management Information Systems are strengthened to ensure that Higher Education performance is following the requirements of students, society, and industry (Gorgan, 2015). The quality management system has also been improved, to provide quality assurance.

Decision support systems have also been proven capable of solving educational problems in tertiary institutions. Fakeeh (2015) reported that Decision Support Systems (DSS) are well recognized in the world of education for a variety of reasons, for example for data conjugation and 
as a smart, highly attractive method that is unmatched and possibly able to provide explanations for various problems and to perfect a decision without a doubt. Klein \& Ronen (2003) show that administrative education decisions are helped by Decision Support Systems (DSS) characterized by pedagogical and organizational orientations that differ from decisions made without computer assistance.

One hundred and ten middle school teachers were asked to suggest solutions to problems that emerged in the two school problems. After reaching a decision, respondents were asked to rank, based on interests, the considerations that guided them. Data is processed by DSS software, which calculates the highest score option for each issue. This option is compared with that chosen by respondents, taking into account variables of seniority, education level, specialization, and selfefficacy. Decisions assisted by DSS promote greater moderation and increase cooperation among interested parties compared to decisions made without computer assistance. The implication of this finding for the division of decision-making tasks between humans and computers in the future is a necessity.

\section{Conclusion}

1. Decision Support System's (DSS) concept according to the headmaster of Madrasa Aliyah Wali Songo Sons dorm and headmaster of Madrasa Aliyah Wali Songo Girls dorm is a set of instruments created by humans with a complex system-assisted (possibly computeraided) who works as a thinker, processor, responder, and recommendations based on the requirements and goals of individuals or organizations specifically in designing integrative madrasa curriculum in Islamic boarding school.

2. Decision-making in designing a curriculum must be performed with a dynamic and static model at the same time. Probably there is a problem during applying the curriculum after the decisions are made. Therefore, the problems will not be handled properly if they only concerning to static model. Decision-making should be carried out by prioritizing consensus agreement from all madrasa residents to avoid unnecessary conflicts of interest. The decision-making step must integrate all the possible models that can be applied such as a combination of verbal, mathematical computer simulation, physical, operational games, and so on. A comprehensive model is taken to solve complex problems that occur and end with the formalization of decisions to ensure the validity of curriculum constructs and the legitimacy of decisions.

3. The madrasa integrative curriculum formulated by Madrasa Aliyah Wali Songo Sons dorm and Madrasa Aliyah Wali Songo Girls dorm is an Independent Curriculum Transdisciplinary (ICT).

\section{References}

Ansani \& Baking, A. (2019). Manajemen kepala madrasah dalam implementasi kurikulum 2013 Di Madrasah Aliyah Negeri 1 Kolaka Kabupaten Kolaka. Jurnal Teknologi Pendidikan Madrasah, 2, 127-145. https://doi.org/10.5281/zenodo.3601123

Anwar, H. (2014). Proses pengambilan keputusan untuk mengembangkan mutu Madrasah. Jurnal Pendidikan Islam, 8(1), $37-56$.

Binus University. (2016). Pengertian sistem informasi. Retrieved December 5, 2019, from http://scdc.binus.ac.id/ website: http://scdc.binus.ac.id/himsisfo/2016/07/pengertian-sistem-informasi/

Eniyati, S. (2011). Perancangan sistem pendukung pengambilan keputusan untuk penerimaan beasiswa dengan metode SAW (Simple Additive Weighting). Jurnal Teknologi Informasi DINAMIK, 16(2), 171-176.

Eriskawati, D., Sari, K. P., Masalah, L. B., \& Rahardjo, A. W. (2006). Sistem pendukung keputusan perekrutan pegawai menggunakan metode simple additive weighting (SAW) pada koperasi Gentiaras. Media Informatika - STMIK Pringsewu.

Evy, R. (2015). Pemahaman siswa ditinjau dari gaya belajar terhadap fungsi trigonometri berdasarkan teori apos (Action, processes, object, and schema) Kelas X SMA Al Azhaar Tulungagung Tahun Pelajaran 2014/2015. IAIN Tulungagung.

Fakeeh, K. A. (2015). Decision Support Systems (DSS) in higher education system. International Journal of Applied Information Systems (IJAIS), 9(2), 32-40. 
Gorgan, V. (2015). Requirement Analysis for a higher education decision support system. evidence from a Romanian University. Procedia - Social and Behavioral Sciences, 197(February), 450-455. https://doi.org/10.1016/j.sbspro.2015.07.165

Hapsari, D. D. (2005). Model pengambilan keputusan, (No. 1).

Klein, J., \& Ronen, H. (2003). The contribution of a decision decision-making processes. Journal Of Educational Computing Research, 28(3), 273-290. https://doi.org/10.2190/3U4E-XQR0-MK52-AGAM

KSKK, D., Direktorat Jenderal Pendidikan Islam, K., \& Indonesia, A. R. (2019a). Keputusan Menteri Agama Nomor 183 Tahun 2019 tentang Kurikulum Pendidikan Agama Islam (PAI) dan Bahasa Arab Pada Madrasah.

KSKK, D., Direktorat Jenderal Pendidikan Islam, K., \& Indonesia, A. R. (2019b). KMA Nomor 184 Tahun 2019 tentang pedoman implementasi kurikulum pada Madrasah. Direktorat KSKK Kementerian Agama RI.

Malihah, Elly Wilodati, Jerry Gytha, L. (2013). Berpikir kreatif dalam pengambilan keputusan. Forum Ilmu Sosial, 40(2), 178-188.

Putranto, A. (2016). Analisis dan desain sistem pendukung pengambilan keputusan pemilihan lokasi unit usaha tour dan travel. Sanata Dharma.

Saliman, S. (2015). Mengenal Decision Support System (DSS). Efisiensi - Kajian Ilmu Administrasi, 10(1), 1-5. https://doi.org/10.21831/efisiensi.v10i1.3971

Sumarsono, H. (2013). Ziarah pemikiran herbert alexander simon. Ekuilibrium - Jurnal Ilmiah Bidang Ilmu Ekonomi, 8(2), 35-45.

Setiyaningsih, W. (2015). Konsep sistem pendukung keputusan. Journal of Chemical Information and Modeling, 53(9), 1689-1699. https://doi.org/10.1017/CB09781107415324.004

Setyawan, T. B. (2015). Penerima beasiswa dengan metode simple additive weighting berbasis java desktop application.

Sumiati, \& Nuryadin, S. (2013). Sistem pendukung keputusan dalam menentukan penilaian kinerja dosen dengan metode Fuzzy Database Model Mamdani. Electrans, 12(2), 161-170.

Suryadi, P. K. (2011). Pidato Ilmiah Guru Besar Institut Teknologi Bandung.

Thora, A. H. F. (2015). Sistem pendukung keputusan untuk menentukan tingkat kerusakan bangunan sekolah dasar menggunakan metode fuzzy logic. UIN Maulana Malik Ibrahim Malang.

Turban, E. (2005). Decision Support Systems and Intellgent Systems-7th Ed. jilid 2 = (Sistem pendukung keputusan dan sistem cerdas) / Efraim Turban, Ting-Peng Liang; Diterjemahkan oleh: Siska Primaningrum (7th ed.). Yogyakarta: Andi.

Whetyningtyas, A. (2011). Peranan Decision Support System (DSS) bagi manajemen selaku decision maker. Jurnal Online, 5(1), 102108. 